\title{
Changes in Soil Properties with Distance in Brick Kiln Areas around Barisal
}

\author{
Anjuman Ara Rajonee*, Md. Jamal Uddin \\ Department of Soil and Environmental Sciences, University of Barisal, Barisal, Bangladesh \\ Email: ^rajonee.du101361@gmail.com
}

How to cite this paper: Rajonee, A.A. and Uddin, Md.J. (2018) Changes in Soil Properties with Distance in Brick Kiln Areas around Barisal. Open Journal of Soil Science, 8, 118-128.

https://doi.org/10.4236/ojss.2018.83009

Received: February 16, 2018

Accepted: March 25, 2018

Published: March 28, 2018

Copyright $\odot 2018$ by authors and Scientific Research Publishing Inc. This work is licensed under the Creative Commons Attribution International License (CC BY 4.0).

http://creativecommons.org/licenses/by/4.0/

\begin{abstract}
The study was conducted to evaluate the changes in soil properties due to the impacts of brick kiln in the vicinity of the Kirtonkhola River, Barisal. The study was carried out by determining the physical, physico-chemical and chemical characteristics of soil. During the entire study period, moisture content of soil ranged from $18.77 \%$ to $56.49 \%$; bulk density and particle density varies from $0.23-0.53 \mathrm{~g} / \mathrm{cm}^{3}$ and $1.11-3.15 \mathrm{~g} / \mathrm{cm}^{3}$, respectively; soil porosity varies from $60.36 \%$ to $88.14 \%$; $\mathrm{pH}$ varies from 6.98 to 8.85 and organic carbon content varies from $0.22 \%$ to $1.4 \%$. The finding revealed that the $\mathrm{pH}$ of the soil decreased with increasing distance from the kiln; moisture content and organic carbon increased with distance; particle density was more or less in ideal condition for plant growth but bulk density and porosity indicates poor soil structure which is unfavourable for plant.
\end{abstract}

\section{Keywords}

Brick Kiln, Kirtonkhola River, Physical Parameters, Organic Carbon

\section{Introduction}

Brick kilns are the major concern of Bangladesh. Bricks are used as a raw material in construction of buildings. It is a growing market in Bangladesh although it has great impacts on the environment. The raw material for brick is "Top soil" that has the great value for agricultural crop production. Clay bricks, in particular, are widely used as a traditional building material. In many developing countries a common method to obtain the clay needed for brick production is by removing the topsoil [1].

The net result of a brick kiln is called land degradation. Land degradation is a reduction of land quality. Productivity of soil declines when land becomes de- 
graded. It declines unless steps are taken to restore that productivity and check further losses. Data analyses on the brick fields from different studies reveal that considerable amount of productive and potential agricultural lands has been given to brick fields. Unfortunately, brick fields are mostly situated on river line fertile agricultural land as it needs clayish, silt and loamy soil with good texture. Removal of fertile top soil leaves the land infertile [2].

$\mathrm{Zn}, \mathrm{Cu}$ and $\mathrm{S}$ concentrations in soils and plants are then the critical limits in the areas nearby brick kilns [3]. They emit a variety of greenhouse gases and heavy metals during the production of brick. Among them $\mathrm{Pb}, \mathrm{Zn}, \mathrm{Hg}, \mathrm{Cu}, \mathrm{Ni}$, $\mathrm{Se}, \mathrm{Fe}$ and $\mathrm{Cd}$ are the most common ones [4].

The major reason for emitting these gases is improper burning of coal and wood [5]; besides these fly-ash is an important polluting agent which contains high concentration of $\mathrm{Na}, \mathrm{K}, \mathrm{Zn}, \mathrm{Mg}$ and $\mathrm{Fe}$ as well as a wide range of heavy metals such as $\mathrm{Hg}, \mathrm{Pb}, \mathrm{Cd}$ and $\mathrm{Zn}$ and non-ferrous metals [6]. Higher content of heavy metal lowers cation exchange capacity of soil, decreases organic carbon content, and then reduces water holding capacity [7].

At present the demand of bricks is soaring, especially in the developing country like Bangladesh, where infrastructure development projects are the top priority. The current population of the country is assessed at around 149 million [8]. A large portion of huge populace is migrating to the urban areas for better living condition. Owing to this rapid urbanization a sharp rise of 5.6 percent per year has been noticed for the construction industry. This trend eventually directed the brick sector to increase annually at a projected 2 - 3 percent over the next decade for housing construction and commercial sector developments [9]. Despite the existence of laws, many of around 11,100 brickfields across the country are still operating in conventional methods such as using wood to burn bricks, damaging arable land by cutting earth and polluting the air by emission, while many other brickfields have been operating just without approval of the authorities concerned including the Department of Environment (DoE). The DoE headquarters, however, has no specific data on the number of brickfields currently operating in the country and the extent of pollution-the amount of emitted smoke and impact of its contents on human, crops, vegetation and land. However, a World Bank study released last year found that in North Dhaka brick kilns are the main source of fine particulate pollution accounting for nearly 40 percent of total emissions during the 5-month operating period.

Very few works has been done to assess the impacts on agri-environments from nearby brick kilns in Bangladesh [3] [4] [10]. Therefore, the current research aims to find out the status of agricultural soil in nearby brick kiln agri-environmental ecosystems.

\section{Materials and Methods}

Soil samples were collected in January 2017, which is the pick period of brick production in that area. Thirty two soil samples were collected from eight dif- 
ferent brick kilns along the bank of Kirtonkhola River. The study covered the brick kilns in $10 \mathrm{~km}$ distance (each one is $1 \mathrm{~km}$ distance from another). The soil samples are collected from 4 points of each kiln area to see the changes with distance in agricultural field. The distances are approximately $0 \mathrm{~km}, 1 \mathrm{~km}, 2 \mathrm{~km}$ and $3 \mathrm{~km}$ distance from the kilns toward the agricultural field. Detailed information about the locations and samples collected from those sites are given in Annexure Table A1.

In case of soil sample collection and preparation, at first existing plants and vegetation were removed from the sampling points with the help of a spade. Then the aluminium core was inserted to take topsoil at a depth of $15 \mathrm{~cm}$ for bulk density analysis and then at least $2 \mathrm{~kg}$ of soil sample was taken into a polythene bag with proper labelling for further analysis. The spade was inserted to the ground as a V-shaped pattern and collected the sample. Three soil samples were collected from each point and composite sample was done by mixing it very well on a piece of paper. Soil samples were carried into the laboratory of Department of Soil and Environmental Sciences, University of Barisal.

Once the soil samples were transported to the laboratory, these were dried in the air for 7 days (at $\sim 30^{\circ} \mathrm{C}$ ) by spreading them in a thin layer on a clean piece of paper. Visible roots and debris were removed from the soil samples and discarded. After air-drying, a portion of larger and massive aggregates were broken down by gently crushing them using a wooden hammer. Ground samples were screened to pass through a $2 \mathrm{~mm}$ stainless steel sieve. The analysis was done as soon as possible to avoid any changes of the sample. The soil samples were collected and prepared according to the Soil Survey Staff [11].

$\mathrm{pH}$ reading was taken using $\mathrm{pH}$ meter (Model: Adwa AD1000 and AD1020) where the ratio of soil: water was 1:2.5. Bulk density of soil was measured using Core method, particle density using pycnometer method and organic carbon determination was done using "Walkley and Black" oxidation method [12]. All the analyses were done using standard procedures as in [12] [13].

A small group discussion with the local people and brick kiln worker was done in each brick kiln to observe the preliminary situations in that area. Microsoft Excel was used for the statistical and graphical evaluations.

\section{Result and Discussion}

A total 8 brick kiln with 32 different spots were selected for sampling and then analysing different basic soil characteristics to observe the changes in properties with variable distance from the kilns to nearby agricultural lands. Detailed analyses were done on the following parameters and are presented in two sections.

\section{1) Changes in some basic physical properties}

Among the parameters physical properties of soil have influence on availability of nutrients to plants, activities of soil macro and microorganisms and also have potency of toxic substances. 


\section{a) Soil moisture}

Soil moisture content is a factor that helps to determine the quality of soil. Soil should be capable of absorbing adequate moisture. If water is lost from soil then soil quality deteriorates. Water holding capacity of soil influences crop growth, rotting pattern, and ability to supply water to crops during dry period [14].

In case of soil moisture content it is observed that the samples have adequate moisture content ranges from $18.77 \%$ to $56.49 \%$ and is increasing with distance from chimney (Figure 1) in every brick kiln sites which corroborates the finding of [15].

\section{b) Bulk density, particle density and porosity of soil samples}

Bulk density is the sign of soil compaction. It normally varies from about 1.2 $1.7 \mathrm{~g} / \mathrm{cm}^{3}$ [12]. Bulk density increases with decreasing soil porosity. The resultant samples have very low porosity ranges from $0.23-0.53 \mathrm{~g} / \mathrm{cm}^{3}$ (Table 1) means that they have large pore spaces present between soil aggregates. This makes it difficult for the plant roots to extract moisture and nutrients. These soils are highly permeable.

Particle density of soil generally ranges from $2.6-3.3 \mathrm{~g} / \mathrm{cm}^{3}$ denotes about the ideal condition of soil. In this experiment particle density of samples ranges from $1.11-3.15 \mathrm{~g} / \mathrm{cm}^{3}$ (Table 1 ) denotes that particle density is more or less in ideal condition.

Soil porosity is the index of penetration resistance [16]. The ideal soil would hold sufficient air and water to meet the needs of plants with enough pore space for easy root penetration [17]. The porosity of collected soil samples ranges from $60.36 \%-88.14 \%$ (Table 1 ) indicates poor soil structure, especially in relation to plant growth [18].

ANOVA analysis was done to see the relationship of bulk density and particle density with soil porosity and shows that bulk density and particle density has significant relationship with soil porosity ( $F$ value 140.13). P value is near to zero indicates that bulk density and particle density is important for porosity analysis. Regression analysis was also done and shows that the adjusted $\mathrm{R}^{2}$ is about $90 \%$ indicates that, as per our sample analysis we can explain the changes of porosity is about $90 \%$ by these two factors.

\section{Moisture content $(\% \mathrm{w})$}

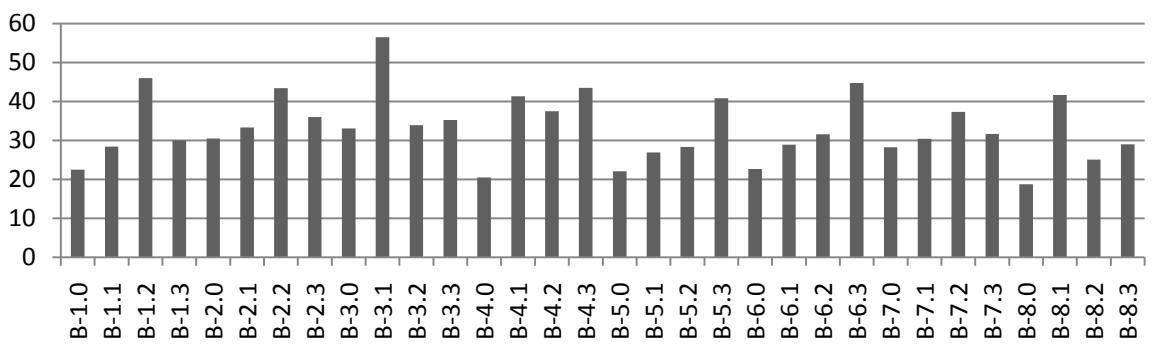

Figure1. Soil moisture content. 
Table 1. Some basic physical properties of soil samples.

\begin{tabular}{|c|c|c|c|}
\hline Sample No. & $\begin{array}{l}\text { Bulk density } \\
\left(\rho_{b}, \mathrm{~g} / \mathrm{cm}^{3}\right)\end{array}$ & $\begin{array}{l}\text { Particle density } \\
\qquad\left(\rho_{s}, \mathrm{~g} / \mathrm{cm}^{3}\right)\end{array}$ & $\begin{array}{c}\text { Porosity } \\
(\phi, \%)\end{array}$ \\
\hline B-1.0 & 0.45 & 2.79 & 83.87 \\
\hline B-1.1 & 0.41 & 2.81 & 85.41 \\
\hline B-1.2 & 0.53 & 3.02 & 82.45 \\
\hline B-1.3 & 0.44 & 2.56 & 82.81 \\
\hline B-2.0 & 0.49 & 2.34 & 79.06 \\
\hline B-2.1 & 0.47 & 2.13 & 77.93 \\
\hline B-2.2 & 0.42 & 2.04 & 79.41 \\
\hline B-2.3 & 0.39 & 1.57 & 75.16 \\
\hline B-3.0 & 0.48 & 2.02 & 76.24 \\
\hline B-3.1 & 0.51 & 1.88 & 72.87 \\
\hline B-3.2 & 0.35 & 2.20 & 84.09 \\
\hline B-3.3 & 0.23 & 1.94 & 88.14 \\
\hline B-4.0 & 0.35 & 1.72 & 79.65 \\
\hline B-4.1 & 0.49 & 1.57 & 68.79 \\
\hline B- 4.2 & 0.42 & 3.15 & 86.67 \\
\hline B-4.3 & 0.41 & 1.84 & 77.72 \\
\hline B-5.0 & 0.39 & 1.98 & 80.30 \\
\hline B-5.1 & 0.40 & 1.94 & 79.38 \\
\hline B-5.2 & 0.42 & 2.15 & 80.47 \\
\hline B-5.3 & 0.52 & 1.80 & 71.11 \\
\hline B-6.0 & 0.47 & 2.12 & 77.83 \\
\hline B-6.1 & 0.38 & 1.67 & 77.25 \\
\hline B-6.2 & 0.49 & 2.06 & 76.21 \\
\hline B-6.3 & 0.53 & 2.14 & 75.23 \\
\hline B-7.0 & 0.43 & 2.13 & 79.81 \\
\hline B-7.1 & 0.44 & 1.11 & 60.36 \\
\hline B-7.2 & 0.50 & 1.71 & 70.76 \\
\hline B-7.3 & 0.46 & 1.93 & 76.17 \\
\hline B-8.0 & 0.32 & 1.95 & 83.59 \\
\hline B-8.1 & 0.53 & 2.26 & 76.55 \\
\hline B-8.2 & 0.39 & 2.00 & 80.50 \\
\hline B-8.3 & 0.44 & 1.81 & 75.69 \\
\hline
\end{tabular}


2) Changes in some physico-chemical and chemical properties of the sampling sites

a) Soil $p H$

Soil $\mathrm{pH}$ is an important index of ecological condition of terrestrial environment. It affects the availability of nutrients to plants and the activity of soil microorganisms. Soil $\mathrm{pH}$ provides a good identification of soil chemical nature where higher $\mathrm{pH}$ indicated optimal range for plant growth but lower $\mathrm{pH}$ causes problems for normal growth of the plants [19].

Though the average $\mathrm{pH}$ of Bangladesh soils could be taken on the acidic side of the $\mathrm{pH}$ scale, between 5.5 and 6.5 [20]; $\mathrm{pH}$ values of the samples ranged from 6.98 to 8.85 (Figure 2). Recorded $\mathrm{pH}$ of soil samples ranged from very slightly acidic to strongly alkaline. The $\mathrm{pH}$ of soil samples at $0 \mathrm{~km}$ is the highest in every brick kiln. Detailed information on soil $\mathrm{pH}$ of the samples is given in Annexure Table A2.

Soil pH

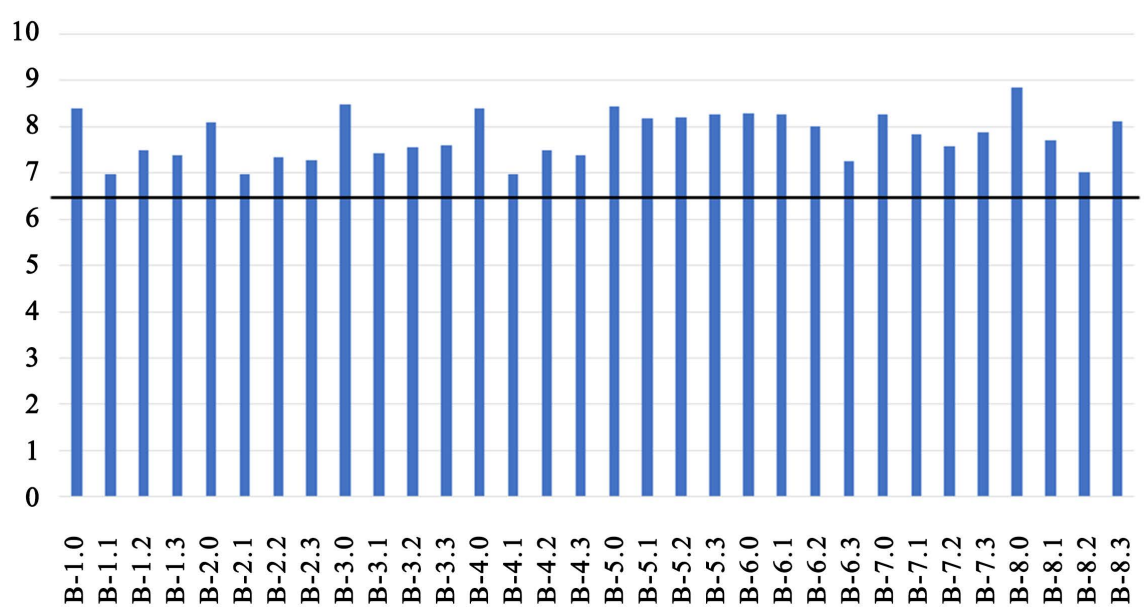

Figure 2. Soil pH.

\section{b) Soil organic carbon}

Soil organic carbon is an important parameter of soil that determines beneficial effects on soil quality. It improves soil structure, enhances aeration and water penetration, increases water holding capacity, and supplies nutrients for plants growth. Organic carbon levels greater than $0.8 \%$ are rated as good quality of soil [19].

A level of organic carbon greater than $0.75 \%$ indicates good fertility [19] [21]. Soil organic carbon in this study area ranged from $0.22 \%$ to $1.4 \%$ (Figure 3 ). The variation of organic carbon may be the result of the variation of organic matter practices and also it is directly related to surface soil removal process. Organic carbon level in soil samples near to brick kiln has been found poor in range. Because of the stabilizing properties that clay has on organic matter, soil texture affects Soil Organic Carbon (SOC) [21]. Detailed information on soil organic carbon of the samples is given in Annexure Table 2. 
Organic Carbon (\%)

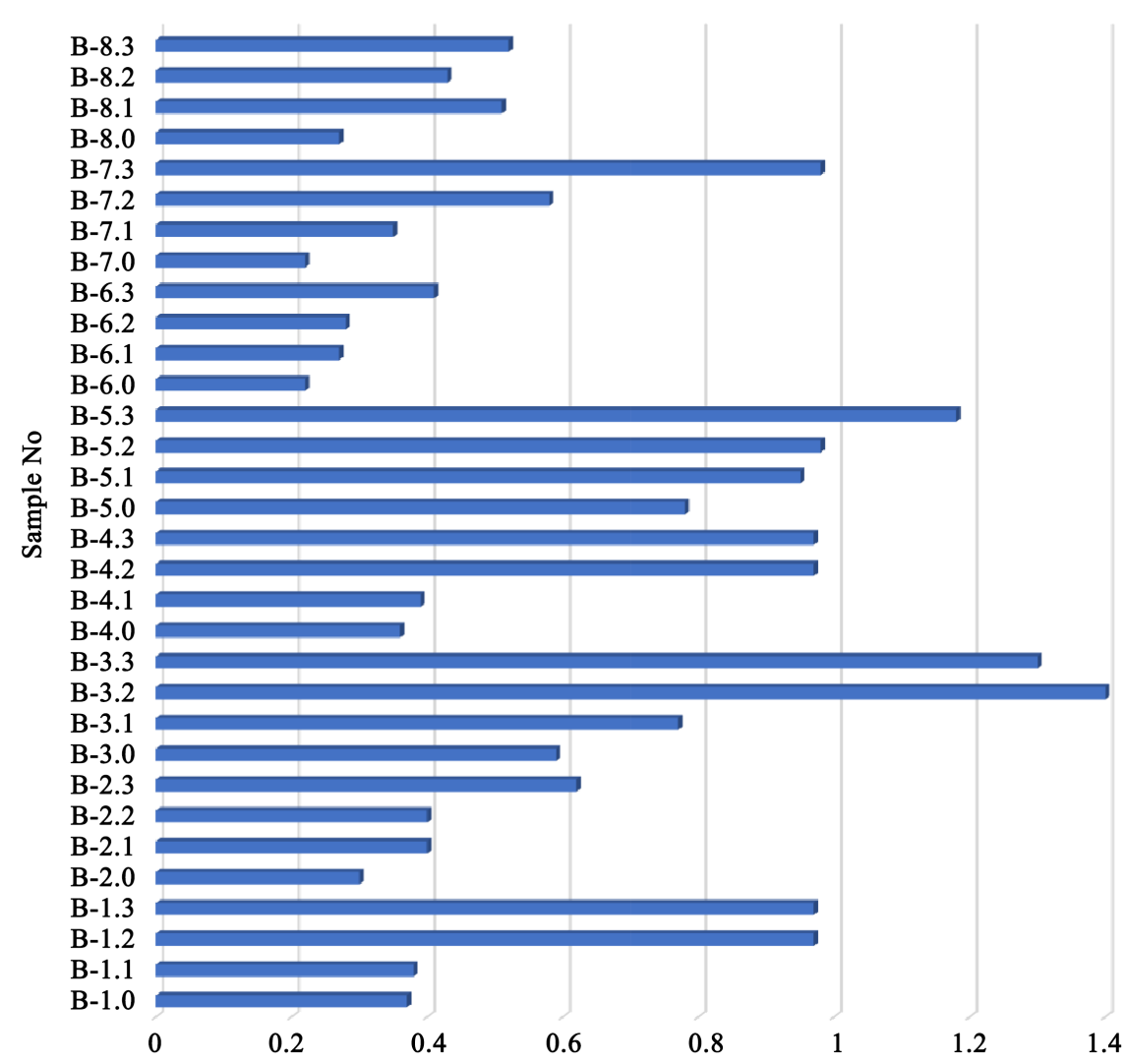

Figure 3. Soil organic carbon.

\section{Conclusion}

The study area ( $1 \mathrm{~km}, 2 \mathrm{~km}$ and $3 \mathrm{~km}$ distance) is mainly used for agricultural cultivation. People in this area depend on agriculture. The study revealed that major properties of soil are not in ideal condition for plant growth. The decrease of soil characteristics might be due to a large number of brick kilns in this area. The peoples living in that area also said that they have got higher crop production in that area but after installations of brick kilns the crop productions decreased with time. The present situation may cause great impacts in the long run. Therefore, further research is required to identify the rate of changes in physical properties as well as in chemical properties of soil in this brick kiln associated agricultural area.

\section{References}

[1] Rahman, M., Ahmed, F., Nafi, F. and Ahmed, S.U. (2015) Use of Topsoil by Brick Fields Threatened for Agricultural Production of Bangladesh. Dresden Nexus Conference, Dresden, 25-27 March 2015.

[2] Das, R. (2015) Causes and Consequences of Land Degradation in and around the Brick Kilns of Khejuri CD Blocks over Coastal Medinipur in West Bengal. International Journal of Innovative Research and Development, 4, 185-194.

[3] Sikder, A.H.F., Begum, K., Parveen, Z. and Hossain, M.F. (2016) Assessment of 
Macro and Micro Nutrients around Brick Kilns Agricultural Environment. Information Processing in Agriculture, 3, 61-68. https://doi.org/10.1016/j.inpa.2016.02.001

[4] Ahmed, S. and Hossain, I. (2008) Applicability of Air Pollution Modeling in a Cluster of Brickfields in Bangladesh. Chemical Engineering Research Bulletin, 12, 28-34. https://doi.org/10.3329/cerb.v12i0.1495

[5] Alam, G.J. (2009) Environmental Pollution of Bangladesh-It's Effect and Control. Pulp and Paper, 51, 13-17.

[6] Luo, L., Ma, Y., Zhang, S., Wei, D. and Zhu, Y.G. (2009) An Inventory of Trace Element Inputs to Agricultural Soils in China. Journal of Environmental Management, 90, 2524-2530. https://doi.org/10.1016/j.jenvman.2009.01.011

[7] Duker, A.A., Carranza, E. and Hale, M. (2005) Arsenic Geochemistry and Health. Environment International, 31, 631-641. https://doi.org/10.1016/j.envint.2004.10.020

[8] BBS (2011) Statistical Yearbook of Bangladesh-2011. 31st Edition, Bangladesh Bureau of Statistics, Dhaka.

[9] World Bank (2010) Introducing Energy-Efficient Clean Technologies in the Brick Sector of Bangladesh. Report No. 60155-BD. Environment, Climate Change and Water Resource Unit, Washington DC.

[10] Akter, R., Uddin, M.J., Hossain, M.F. and Parveen, Z. (2016) Influence of Brick Manufacturing on Phosphorus and Sulfur in Different Agro-Ecological Soils of Bangladesh. Bangladesh Journal of Scientific Research, 29, 123-131. https://doi.org/10.3329/bjsr.v29i2.32329

[11] USDA (United States Department of Agriculture) (1951) Soil Survey Manual. Handbook No. 18, Soil Survey Staff, Bureau of Plant Industry, Soils and Agricultural Engineering, United States Department of Agriculture, Washington DC, 205.

[12] Huq, S.M.I. and Alam, M.D. (2005) A Handbook on Analyses of Soil, Plant and Water. Bangladesh-Australia Center for Environmental Research (BACER-DU), University of Dhaka, Dhaka, 1-246.

[13] Jackson, M.L. (1973) Soil Chemical Analysis. Prentice-Hall, Inc.., Englewood Cliffs, NJ.

[14] Debnath, P., Deb, P., Sen, D., Pattannaik, S.K., Sah, D. and Ghosh, S.K. (2012) Physico-Chemical Properties and its Relationship with Water Holding Capacity of Cultivated Soils along Altitudinal Gradient in Sikkim. International Journal of Agriculture, Environment and Biotechnology, 5, 99-102.

[15] Bisht, G. and Neupane, S. (2015) Impact of Brick Kilns' Emission on Soil Quality of Agriculture Fields in the Vicinity of Selected Bhaktapur Area of Nepal. Applied and Environmental Soil Science, 2015, Article ID: 409401, 8 p.

[16] Carter, M.R. (1990) Relationship of Strength Properties to Bulk Density and Macroporosity in Cultivated Loamy Sand to Loam Soils. Soil and Tillage Research, 15, 257-268. https://doi.org/10.1016/0167-1987(90)90082-O

[17] Chaudhari, P.R., Ahire, D.V., Ahire, V.D., Chkravarty, M. and Maity, S. (2013) Soil Bulk Density as Related to Soil Texture, Organic Matter Content and Available Total Nutrients of Coimbatore Soil. International Journal of Scientific and Research Publications, 3, 1-8.

[18] Pagliai, M. and Vignozzi, N. (2002) Image Analysis and Microscopic Techniques to Characterize Soil Pore System. In: Blahovec, J. and Kutíllek, M., Eds., Physical Methods in Agriculture, Springer, Boston, 13-38. https://doi.org/10.1007/978-1-4615-0085-8_2 
[19] Yaseen, S., Pal, A., Singh, S. and Skinder, B.M. (2015) Soil Quality of Agricultural Fields in the Vicinity of Selected Mining Areas of Raniganj Coalfield India. Journal of Environmental\& Analytical Toxicology, 5, 1-6.

[20] Huq, S.I. and Shoaib, J.M. (2016) The Soils of Bangladesh. Springer, Berlin.

[21] Ghosh, A.B., Bajaj, J.C., Hasan, R. and Singh, D. (1983) Soil and Water Testing Methods: A Laboratory Manual. IARI, New Delhi, 31-36. 


\section{Annexure}

Table A1. Sample number with corresponding location detail.

\begin{tabular}{|c|c|c|c|c|}
\hline $\begin{array}{l}\text { Brickfield } \\
\text { number }\end{array}$ & $\begin{array}{l}\text { Collected } \\
\text { point }\end{array}$ & Latitude & Longitude & $\begin{array}{l}\text { Denoted } \\
\text { Number }\end{array}$ \\
\hline \multirow{4}{*}{1} & $0 \mathrm{~km}$ & $22^{\circ} 41^{\prime} 24^{\prime \prime} \mathrm{N}$ & $90^{\circ} 22^{\prime} 38.2^{\prime \prime} \mathrm{E}$ & B-1.0 \\
\hline & $1 \mathrm{~km}$ & $22^{\circ} 41^{\prime} 27.1 " \mathrm{~N}$ & $90^{\circ} 22^{\prime} 51.2^{\prime \prime} \mathrm{E}$ & B-1.1 \\
\hline & $2 \mathrm{~km}$ & $22^{\circ} 41^{\prime} 25.8^{\prime \prime} \mathrm{N}$ & $90^{\circ} 22^{\prime} 58^{\prime \prime} \mathrm{E}$ & B-1.2 \\
\hline & $3 \mathrm{~km}$ & $22^{\circ} 40^{\prime} 56^{\prime \prime} \mathrm{N}$ & $90^{\circ} 23^{\prime} 17.2^{\prime \prime} \mathrm{E}$ & B-1.3 \\
\hline \multirow{4}{*}{2} & $0 \mathrm{~km}$ & $22^{\circ} 41^{\prime} 13^{\prime \prime} \mathrm{N}$ & $90^{\circ} 22^{\prime} 36.1^{\prime \prime} \mathrm{E}$ & B-2.0 \\
\hline & $1 \mathrm{~km}$ & $22^{\circ} 41^{\prime} 11.8^{\prime \prime} \mathrm{N}$ & $90^{\circ} 22^{\prime} 45.9^{\prime \prime} \mathrm{E}$ & B-2.1 \\
\hline & $2 \mathrm{~km}$ & $22^{\circ} 41^{\prime} 11.2^{\prime \prime} \mathrm{N}$ & $90^{\circ} 22^{\prime} 52.6^{\prime \prime} \mathrm{E}$ & B-2.2 \\
\hline & $3 \mathrm{~km}$ & $22^{\circ} 40^{\prime} 57.3^{\prime \prime} \mathrm{N}$ & $90^{\circ} 23^{\prime} 10.9^{\prime \prime} \mathrm{E}$ & B-2.3 \\
\hline \multirow{4}{*}{3} & $0 \mathrm{~km}$ & $22^{\circ} 41^{\prime} 4.4^{\prime \prime} \mathrm{N}$ & $90^{\circ} 22^{\prime} 41.6^{\prime \prime} \mathrm{E}$ & B-3.0 \\
\hline & $1 \mathrm{~km}$ & $22^{\circ} 40^{\prime} 57.9^{\prime \prime} \mathrm{N}$ & $90^{\circ} 22^{\prime} 48.7^{\prime \prime} \mathrm{E}$ & B-3.1 \\
\hline & $2 \mathrm{~km}$ & $22^{\circ} 40^{\prime} 57^{\prime \prime} \mathrm{N}$ & $90^{\circ} 22^{\prime} 59.6^{\prime \prime} \mathrm{E}$ & B-3.2 \\
\hline & $3 \mathrm{~km}$ & $22^{\circ} 40^{\prime} 55.4^{\prime \prime} \mathrm{N}$ & $90^{\circ} 23^{\prime} 7.4^{\prime \prime} \mathrm{E}$ & B-3.3 \\
\hline \multirow{4}{*}{4} & $0 \mathrm{~km}$ & $22^{\circ} 40^{\prime} 38.4^{\prime \prime} \mathrm{N}$ & $90^{\circ} 22^{\prime} 15.7^{\prime \prime} \mathrm{E}$ & B- 4.0 \\
\hline & $1 \mathrm{~km}$ & $22^{\circ} 40^{\prime} 37^{\prime \prime} \mathrm{N}$ & $90^{\circ} 22^{\prime} 28^{\prime \prime} \mathrm{E}$ & B-4.1 \\
\hline & $2 \mathrm{~km}$ & $22^{\circ} 40^{\prime} 21^{\prime \prime} \mathrm{N}$ & $90^{\circ} 22^{\prime} 46.9^{\prime \prime} \mathrm{E}$ & B- 4.2 \\
\hline & $3 \mathrm{~km}$ & $22^{\circ} 40^{\prime} 19.9^{\prime \prime} \mathrm{N}$ & $90^{\circ} 22^{\prime} 30.1^{\prime \prime} \mathrm{E}$ & B-4.3 \\
\hline \multirow{4}{*}{5} & $0 \mathrm{~km}$ & $22^{\circ} 40^{\prime} 25.2^{\prime \prime} \mathrm{N}$ & $90^{\circ} 22^{\prime} 6.5^{\prime \prime} \mathrm{E}$ & B-5.0 \\
\hline & $1 \mathrm{~km}$ & $22^{\circ} 40^{\prime} 27.2^{\prime \prime} \mathrm{N}$ & $90^{\circ} 22^{\prime} 23.2^{\prime \prime} \mathrm{E}$ & B-5.1 \\
\hline & $2 \mathrm{~km}$ & $22^{\circ} 40^{\prime} 9.9^{\prime \prime} \mathrm{N}$ & $90^{\circ} 22^{\prime} 29.2^{\prime \prime} \mathrm{E}$ & B-5.2 \\
\hline & $3 \mathrm{~km}$ & $22^{\circ} 39^{\prime} 59^{\prime \prime} \mathrm{N}$ & $90^{\circ} 22^{\prime} 32.3^{\prime \prime} \mathrm{E}$ & B-5.3 \\
\hline \multirow{4}{*}{6} & $0 \mathrm{~km}$ & $22^{\circ} 40^{\prime} 13.5^{\prime \prime} \mathrm{N}$ & $90^{\circ} 21^{\prime} 21^{\prime \prime E}$ & B-6.0 \\
\hline & $1 \mathrm{~km}$ & $22^{\circ} 40^{\prime} 00^{\prime \prime} \mathrm{N}$ & $90^{\circ} 21^{\prime} 16.2^{\prime \prime E}$ & B-6.1 \\
\hline & $2 \mathrm{~km}$ & $22^{\circ} 39^{\prime} 54^{\prime \prime} \mathrm{N}$ & $90^{\circ} 21^{\prime} 5.2^{\prime \prime} \mathrm{E}$ & B-6.2 \\
\hline & $3 \mathrm{~km}$ & $22^{\circ} 39^{\prime} 38.6^{\prime \prime} \mathrm{N}$ & $90^{\circ} 20^{\prime} 56.2^{\prime \prime} \mathrm{E}$ & B-6.3 \\
\hline \multirow{4}{*}{7} & $0 \mathrm{~km}$ & $22^{\circ} 39^{\prime} 17.9^{\prime \prime} \mathrm{N}$ & $90^{\circ} 21^{\prime} 17.2^{\prime \prime} \mathrm{E}$ & B-7.0 \\
\hline & $1 \mathrm{~km}$ & $22^{\circ} 39^{\prime} 21.3^{\prime \prime} \mathrm{N}$ & $90^{\circ} 21^{\prime} 39.7^{\prime \prime} \mathrm{E}$ & B-7.1 \\
\hline & $2 \mathrm{~km}$ & $22^{\circ} 39^{\prime} 33.5^{\prime \prime} \mathrm{N}$ & $90^{\circ} 22^{\prime} 7 " \mathrm{E}$ & B-7.2 \\
\hline & $3 \mathrm{~km}$ & $22^{\circ} 39^{\prime} 54.4^{\prime \prime} \mathrm{N}$ & $90^{\circ} 22^{\prime} 28.8^{\prime \prime} \mathrm{E}$ & B-7.3 \\
\hline \multirow{4}{*}{8} & $0 \mathrm{~km}$ & $22^{\circ} 39^{\prime} 20.4^{\prime \prime} \mathrm{N}$ & $90^{\circ} 21^{\prime} 16.4^{\prime \prime} \mathrm{E}$ & B-8.0 \\
\hline & $1 \mathrm{~km}$ & $22^{\circ} 39^{\prime} 24.3^{\prime \prime} \mathrm{N}$ & $90^{\circ} 21^{\prime} 39.9^{\prime \prime} \mathrm{E}$ & B- 8.1 \\
\hline & $2 \mathrm{~km}$ & $22^{\circ} 39^{\prime} 35.2^{\prime \prime} \mathrm{N}$ & $90^{\circ} 22^{\prime} 4.9^{\prime \prime} \mathrm{E}$ & B- 8.2 \\
\hline & $3 \mathrm{~km}$ & $22^{\circ} 39^{\prime} 53.1^{\prime \prime} \mathrm{N}$ & $90^{\circ} 22^{\prime} 29.5^{\prime \prime} \mathrm{E}$ & B- 8.3 \\
\hline
\end{tabular}


Table A2. Physico-chemical and chemical properties of soil samples.

\begin{tabular}{|c|c|c|}
\hline Sample no. & Soil pH & Organic Carbon (\%) \\
\hline B-1.0 & 8.39 & 0.37 \\
\hline B-1.1 & 6.98 & 0.38 \\
\hline B-1.2 & 7.48 & 0.97 \\
\hline B-1.3 & 7.37 & 0.97 \\
\hline B-2.0 & 8.08 & 0.30 \\
\hline B-2.1 & 6.98 & 0.40 \\
\hline B-2.2 & 7.33 & 0.40 \\
\hline B-2.3 & 7.27 & 0.62 \\
\hline B-3.0 & 8.48 & 0.59 \\
\hline B-3.1 & 7.43 & 0.77 \\
\hline B-3.2 & 7.54 & 1.40 \\
\hline B-3.3 & 7.59 & 1.30 \\
\hline B- 4.0 & 8.39 & 0.36 \\
\hline B-4.1 & 6.98 & 0.39 \\
\hline B-4.2 & 7.48 & 0.97 \\
\hline B-4.3 & 7.37 & 0.97 \\
\hline B-5.0 & 8.43 & 0.78 \\
\hline B-5.1 & 8.17 & 0.95 \\
\hline B-5.2 & 8.20 & 0.98 \\
\hline B-5.3 & 8.25 & 1.18 \\
\hline B-6.0 & 8.29 & 0.22 \\
\hline B-6.1 & 8.25 & 0.27 \\
\hline B-6.2 & 8.01 & 0.28 \\
\hline B-6.3 & 7.26 & 0.41 \\
\hline B-7.0 & 8.26 & 0.22 \\
\hline B-7.1 & 7.84 & 0.35 \\
\hline B-7.2 & 7.57 & 0.58 \\
\hline B-7.3 & 7.87 & 0.98 \\
\hline B-8.0 & 8.85 & 0.27 \\
\hline B-8.1 & 7.70 & 0.51 \\
\hline B-8.2 & 7.01 & 0.43 \\
\hline B-8.3 & 8.10 & 0.52 \\
\hline
\end{tabular}

